\title{
Bone Marrow-derived Osteoclast-like Cells from a Patient with Craniometaphyseal Dysplasia Lack Expression of Osteoclast-reactive Vacuolar Proton Pump
}

\author{
Takehisa Yamamoto, Noriyoshi Kurihara, * Kanji Yamaoka, Keiichi Ozono, Masato Okada, ${ }^{\star}$ Katsusuke Yamamoto, \\ Sayuri Matsumoto, Toshimi Michigami, Jiro Ono, and Shintaro Okada \\ Department of Pediatrics, Osaka University School of Medicine, Osaka 553, Japan; * Department of Periodontology, \\ Faculty of Dentistry, Meikai University, Sakado 350-02, Japan; and ${ }^{\ddagger}$ Division of Protein Metabolism, \\ Institute for Protein Research, Osaka University, Suita 565, Japan
}

\section{Abstract}

Craniometaphyseal dysplasia (CMD) is a rare craniotubular bone dysplasia transmitted in autosomal dominant or recessive form. This disease is characterized by cranial bone hyperostosis and deformity of the metaphyses of the long bones. Using osteoclast-like cells formed from patient bone marrow cells, we investigated the pathophysiology of CMD in a 3-yr-old patient.

Untreated bone marrow cells from the patient differentiated into osteoclast-like cells in vitro. These cells were shown to have vitronectin $\beta$-receptors using a specific monoclonal antibody, i.e., 23C6 (CD51), which reacts with osteoclasts in human bone biopsy samples. However, the number of these osteoclast-like cells formed from the patient's bone marrow was only $40 \%$ of the normal controls. 1,25-dihydroxyvitamin- $D_{3}$, bovine 1-34 parathyroid hormone, recombinant human interleukin-1 $\beta$, recombinant human interleukin-6, or recombinant human macrophage colony-stimulating factor significantly increased, while salmon calcitonin significantly inhibited, the number of osteoclast-like cells. However, these cells could not resorb sperm whale dentin slices and lacked the osteoclast-reactive vacuolar proton pump as evidenced by a monoclonal antibody (E11). Western blot analysis using a monoclonal antibody to pp60 $^{\text {c-src }}(327)$ revealed that protooncogene c-src expression by the platelets of the CMD patient was comparable to the normal control.

These data suggest that: $(a)$ the hyperostosis and the metaphyseal long bone deformity in the present CMD patient might be explained by osteoclast dysfunction due to impaired expression of the osteoclast-reactive vacuolar proton pump; and (b) a protooncogene c-src was not associated with the pathogenesis of the present CMD patient. (J. Clin. Invest. 1993. 91:362367.) Key words: hyperostosis • bone resorption • osteotropic growth factors $\bullet$ vitronectin $\beta$ receptor $\bullet$ vacuolar proton pump

Address correspondence to Dr. K. Yamaoka, Department of Pediatrics, Osaka University School of Medicine, Osaka 553, Japan.

Received for publication 14 May 1992 and in revised form 2 September 1992.

\section{J. Clin. Invest.}

(C) The American Society for Clinical Investigation, Inc.

$0021-9738 / 93 / 01 / 0362 / 06 \$ 2.00$

Volume 91, January 1993, 362-367

\section{Introduction}

Craniometaphyseal dysplasia (CMD) ${ }^{1}$ is a rare genetic sclerosing metabolic bone disease transmitted in autosomal dominant (1-3) or recessive form (4-6). It is characterized by hyperostosis of the skull and abnormal modeling of the metaphyses of the long bones (1-6). This disease is clinically different from other typical bone sclerosing diseases, such as osteopetrosis (7), in that the bone sclerosis is localized in the skull and sometimes in the diaphyses of the long bones in young children, whereas in osteopetrosis, systemic bone sclerosis usually is observed. In osteopetrosis, two different patterns of pathogenesis have been elucidated in animal models of this disease: one is an abnormality of the precursor of osteoclasts $(8,9)$, and the other is some abnormal bone marrow circumstance in which the differentiation of osteoclasts is impaired. For example, in op/op mice (10), in the osteopetrotic animal model, evidence of a deficiency in macrophage colony-stimulating factor (M-CSF) (11) was reported. In addition, a point mutation in the Csfm gene for M-CSF was elucidated (12), and the protooncogene c-src was reported to be associated with the pathogenesis of osteopetrosis in a new transgenic osteopetrotic mouse line (13).

In contrast, there are no animal models of CMD, and the pathogenesis of this disease has remained obscure. Based on clinical observations, it has been postulated that $C M D$ involves an osteoclast dysfunction that prevents bone resorption (5). In this paper, using a culture method for obtaining intact human osteoclast function in a CMD patient in terms of osteoclast formation, bone resorbing activity, and the osteoclast-reactive vacuolar proton pump expression. Using Western blot analysis, we also investigated the possibility of association of the protooncogene c-src with the pathogenesis of the osteosclerosis in the CMD patient.

\section{Methods}

Materials. $1,25(\mathrm{OH})_{2} \mathrm{D}_{3}$ was a gift from Dr. Ishizuka (Teijin Institute for BioMedical Research, Tokyo, Japan). Bovine 1-34 PTH was obtained from Bachem, California (Torrance, CA). Recombinant human interleukin $1 \beta$ (IL- $1 \beta$ ) was provided by Otsuka Pharmaceuticals (Tokushima, Japan). Recombinant human IL-6 was a gift from Dr. Akiyama (Ajinomoto, Inc., Tokyo, Japan). Recombinant human M-

1. Abbreviations used in this paper: CMD, craniometaphyseal dysplasia; M-CSF, macrophage colony-stimulating factor. 
CSF was provided by Genzyme Corp. (Cambridge, MA). Salmon calcitonin was obtained from Rorer Pharmaceuticals (Ft. Washington, PA). Horse serum was obtained from Hyclone Laboratories, Inc. (Logan, UT). Minimal essential medium ( $\alpha$-MEM) was obtained from Gibco Laboratories (Grand Island, NY), while 35-mm petri dishes and 96-well culture plates were obtained from Becton Dickinson \& Co. (Lincoln Park, NJ), and the ABC-AP kit was purchased from Vector Laboratories, Inc. (Burlingame, CA ). A murine monoclonal antibody, 23C6, which preferentially binds to osteoclasts (14), was generously provided by Dr. Michael Horton (St. Bartholomew's Hospital, London, UK). E11 monoclonal antibody was a generous gift from Dr. Stephen L. Gluck (Jewish Hospital, Washington University Medical Center, St. Louis, MO). This antibody was generated against a peptide from the carboxy-terminal region of the bovine vacuolar proton pump 31,000-mol subunit (15).

Study subject. The subject was a male patient, $3 \mathrm{yr}$ and 2 mo old, born to an unrelated Japanese couple after an uneventful 38-wk pregnancy. The eventual diagnosis was craniometaphyseal dysplasia and there was no family history of a similar disorder. At 1 yr of age, the parents were alarmed by progressive widening of the nasal root with hyperterolism, and broad overgrowth of the base of the nose. He also had progressive macrocephaly. He was referred to Osaka University Hospital for detailed examinations. On admission, the patient was 13.6 $\mathrm{kg}$ in weight (mean), $88.6 \mathrm{~cm}$ in height $(-2 \mathrm{SD})$, and had a head circumference of $54.5 \mathrm{~cm}(+3 \mathrm{SD})$. Neither anemia nor hepatosplenomegaly was observed. His developmental quotient was 85 . No facial or optic nerve palsy was observed, but the patient had a slight speech problem due to mild hearing loss, which was confirmed by the auditory brain stem response. Roentogenograms of the skull showed hyperostosis in the frontal, occipital and skull base areas with very poor neumatoidation of mastoid cells. At the distal end of the femur, the metaphysis was widened, and the diaphysis of the tibia was sclerotic (Fig. 1). The spine and iliac bone did not show evidence of sclerosis. Computed tomography of the skull showed bone overgrowth in the frontal, petrosal, temporal, occipital, and skull base areas, with a slightly narrowed internal auditory canal. Bone biopsy was not performed because the parents refused. Serum and urinary samples were collected between 0800 and $1000 \mathrm{~h}$ for biochemical determinations after an overnight fast. Serum calcium, phosphorus, magnesium, creatinine, and alkaline phosphatase were measured by an autoanalyser ( $80-\mathrm{S}$; Toshiba, Tokyo, Japan). Serum immunoreactive PTH was determined using a kit (Yamasa Shoyu Co., Choshi, Japan). This assay used a chicken anti-human PTH (43-68) antibody. Serum calcitonin was determined using an RIA kit (Daiichi Radioisotope, Inc., Tokyo, Japan). The serum osteocalcin concentration was determined by an immunoradiometric method (Mitsubishi Yuka Co., Ibaraki, Japan). This assay used two types of monoclonal antibodies, which were specifically developed against the $\mathrm{COOH}$-terminal (30-49) and midregion (12-33) of human osteocalcin molecules, respectively (16). Urinary calcium, phosphorus and creatinine were measured by an autoanalyser (mode 7250; Hitachi, Tokyo, Japan). Urinary hydroxyproline was measured by an HPLC method. Serum $1,25(\mathrm{OH})_{2} \mathrm{D}$ was measured by a radioreceptor assay, and serum $250 H D$ was measured by a competitive proteinbinding assay, as previously reported (17).

Osteoclast-like cell formation. Bone marrow cells were aspirated from the iliac crest and used for experiments to obtain osteoclast-like cells, as previously reported (18). In brief, bone marrow cells were applied to Ficoll-Paque. After centrifugation, mononuclear cells were poured into a plastic dish to deplete the adherent cells. The nonadherent cells $\left(1 \times 10^{5} /\right.$ well $)$ were cultured in $\alpha$ MEM containing $20 \%$ horse serum with and without $1,25(\mathrm{OH})_{2} \mathrm{D}_{3}\left(10^{-10}-10^{-8} \mathrm{M}\right)$, bovine 1-34PTH (5-500 ng/ml), recombinant human IL-1 $\beta(50-5,000 \mathrm{pg} /$ $\mathrm{ml})$, recombinant human IL-6 $(10-1,000 \mathrm{pg} / \mathrm{ml})$, or recombinant human M-CSF $(5-500 \mathrm{pg} / \mathrm{ml})$ for $3 \mathrm{wk}$. The cells were then stained with 23C6 (CD51), which preferentially binds to osteoclasts (14), followed by staining with avidin-biotin-conjugated rabbit anti-mouse IgG coupled to alkaline phosphatase using the ABC-AP kit (Vector Laboratories Inc.).
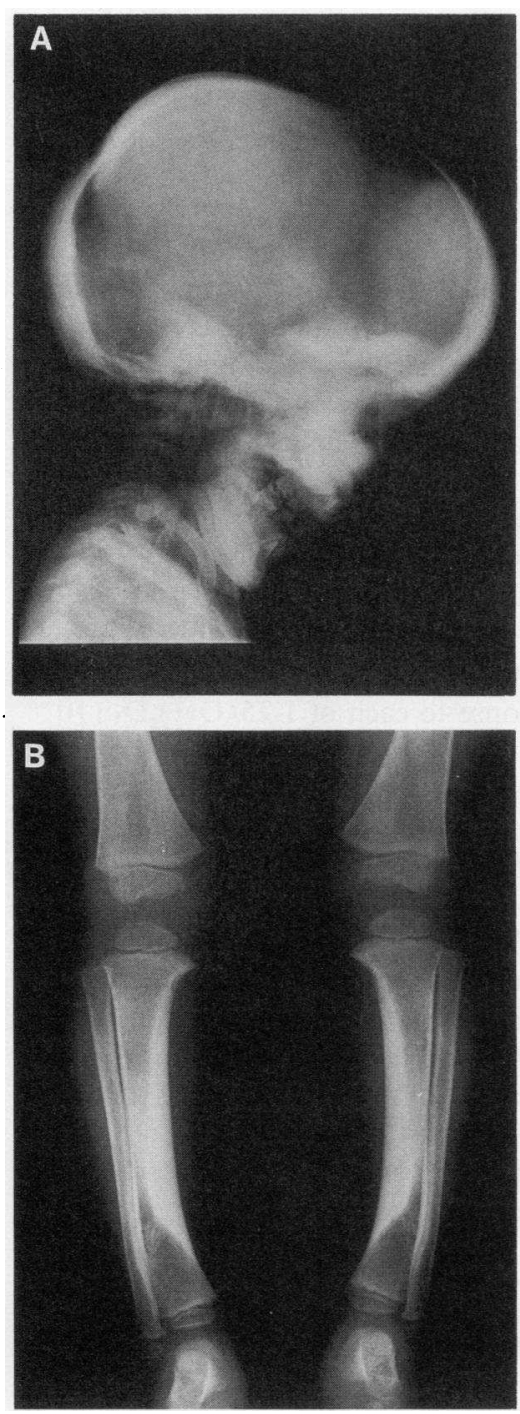

Figure 1. (A) Roentogenogram of the skull taken at $3 \mathrm{yr}$ and 2 mo of age. Marked sclerosis is observed in the frontal, occipital, and skull base areas, with reduced pneumatoidation of mastoid cells. $(B)$ Roentogenogram of the long bones of legs. The metaphysis at the distal end of the femur is widened, and the diaphysis of the tibia is sclerotic.

Bone resorption study. As previously reported (18), the osteoclastlike cells were cultured for $1 \mathrm{wk}$ on sperm whale dentin slices with $\alpha$ MEM-20\% horse serum containing recombinant human IL- $1 \beta$ ( 500 $\mathrm{pg} / \mathrm{ml}$ ). The dentin slices were ultrasonicated in $0.25 \mathrm{M} \mathrm{NaOH}$ for $30 \mathrm{~s}$ to remove the cells, treated with hexamethyl-disizane, air dried, and sputter coated with gold palladium. Finally, the dentin slices were examined by scanning electron microscopy.

Staining of vacuolar proton pump. Using an antibody reacted with the osteoclast vacuolar proton pump (E11) (15), we stained the osteoclast-like cells, as previously reported (19). In brief, the cells were rinsed with PBS, fixed in B5-formalin and incubated for $45 \mathrm{~min}$ at room temperature with E11 antibody, diluted in a Triton X-100 SDS buffer. The cells were then rinsed with the same buffer and incubated with FITC-conjugated rabbit anti-mouse IgG for $30 \mathrm{~min}$ at room temperature. The slices were thoroughly rinsed with PBS and then viewed with an Olympus fluorescence microscope equipped with an automatic camera.

Western blot analysis. The platelet-rich plasma fraction was obtained by centrifuging $10 \mathrm{ml}$ of blood sample which was prepared in a calcium- and magnesium-free PBS solution containing 5\% EDTA. This fraction was subjected to SDS-PAGE ( $10 \% \mathrm{gel})$ and transferred to a nitrocellulose membrane. Anti-c-src monoclonal antibody of 327 (20) was used for immunostaining of protein bands by the method of Cooper and Runge (21), except that the antigens were detected with peroxidase-antiperoxidase complex (22). 
Statistical analysis. The results were reported as the mean \pm SD of triplicate cultures. The data were analyzed by a two-way analysis of variance.

\section{Results}

Laboratory data. The serum calcium, phosphorus, and magnesium values were normal. The serum alkaline phosphatase activity and urinary hydroxyproline excretion were both elevated. The urinary calcium/creatinine ratio was slightly increased. The serum PTH, calcitonin, 25OHD, and $1,25(\mathrm{OH})_{2} \mathrm{D}$ levels were all normal. The serum tartrate-resistant acid phosphatase activity was increased. The serum osteocalcin level was slightly decreased (Table I).

Osteoclast-like cell formation. In the case of normal human bone marrow cells, $\sim 100$ 23C6-positive osteoclast-like cells/ well were formed reproducibly without any hormonal stimulation (23), while about 200 23C6-positive osteoclast-like cells/ well were formed in response to each of $1,25(\mathrm{OH})_{2} \mathrm{D}_{3}\left(10^{-8}\right.$ M), PTH ( $50 \mathrm{ng} / \mathrm{ml}), \mathrm{IL}-1 \beta(5,000 \mathrm{pg} / \mathrm{ml})$, IL-6( $100 \mathrm{pg} / \mathrm{ml})$ (23), and M-CSF ( $500 \mathrm{pg} / \mathrm{ml}$ ) (Kurihara, N. unpublished observations).

However, the patient's bone marrow cells were able to form only $\sim 40$ 23C6-positive osteoclast-like cells/well. $1,25(\mathrm{OH})_{2} \mathrm{D}_{3}$, bovine 1-34 PTH, recombinant human IL- $1 \beta$, recombinant human IL-6 and recombinant human M-CSF were each able to increase significantly the number of 23C6-positive osteoclast-like cells formed. Calcitonin, on the other hand, significantly inhibited the formation of 23C6-positive osteoclast-like cells ( Table II).

Bone resorption study. After culturing the osteoclast-like cells obtained from normal bone marrow cells on sperm whale

Table I. Serum and Urinary Parameters for Bone Metabolism in a CMD Patient

\begin{tabular}{|c|c|c|}
\hline Parameter of bone metabolism & Patient & Normal control \\
\hline \multicolumn{3}{|l|}{ Serum } \\
\hline Calcium $(m g / d l)$ & 9.2 & $(8.8-10.6)$ \\
\hline Phosphorus $(m g / d l)$ & 4.8 & $(3.6-5.6)$ \\
\hline Magnesium (meq/liter) & 1.4 & $(1.4-2.0)$ \\
\hline Alkaline phosphatase (IU/liter) & 1138 & $(115-391)$ \\
\hline \multicolumn{3}{|l|}{ Tartrate-resistant acid } \\
\hline phosphatase (mIU/liter) & 23.4 & $(2.2-9.4)$ \\
\hline PTH $(p g / m l)$ & 199 & $(137-465)$ \\
\hline Calcitonin $(p g / m l)$ & 103 & $(<100)$ \\
\hline Osteocalcin $(n g / m l)$ & 12.3 & $(16-29)$ \\
\hline $25 \mathrm{OHD}(\mathrm{ng} / \mathrm{ml})$ & 9.4 & $(9-29)$ \\
\hline $1,25(\mathrm{OH})_{2} \mathrm{D}(\mathrm{pg} / \mathrm{ml})$ & 61 & $(13-79)$ \\
\hline \multicolumn{3}{|l|}{ Urine } \\
\hline Calcium/creatinine & 0.235 & $(<0.21)$ \\
\hline $\begin{array}{l}\text { Tubular reabsorption of } \\
\text { phosphate (\%) }\end{array}$ & 81.5 & $(85-95)$ \\
\hline $\begin{array}{l}\text { Hydroxyproline/creatinine } \\
\text { ( } \mu \mathrm{mol} / \mathrm{mg} \mathrm{Cr})\end{array}$ & 3.03 & $(0.03-2.5)$ \\
\hline
\end{tabular}

Serum and urinary samples were collected in the morning, after an overnight fast. Note that serum alkaline phosphatase, tartrate-resistant acid phosphatase, and urinary hydroxyproline excretion were elevated.
Table II. Effects of Osteotropic Factors on Osteoclast-like Cell Formation from Patient Bone Marrow

\begin{tabular}{|c|c|c|c|}
\hline \multirow[b]{2}{*}{ Treatment } & \multicolumn{3}{|c|}{ Number of 23C6-positive osteoclast-like cells } \\
\hline & Experiment 1 & Experiment 2 & $\begin{array}{l}\text { Normal } \\
\text { control }\end{array}$ \\
\hline Medium & $43 \pm 2$ & $48 \pm 5$ & $113 \pm 6$ \\
\hline \multicolumn{4}{|l|}{$1,25(\mathrm{OH})_{2} \mathrm{D}_{3}$} \\
\hline $10^{-10} \mathrm{M}$ & $49 \pm 9$ & $72 \pm 5^{*}$ & \\
\hline $10^{-9} \mathrm{M}$ & $66 \pm 11^{\ddagger}$ & $64 \pm 9^{\ddagger}$ & \\
\hline $10^{-8} \mathrm{M}$ & $85 \pm 18^{*}$ & $78 \pm 10^{*}$ & $290 \pm 23^{*}$ \\
\hline \multicolumn{4}{|l|}{ PTH } \\
\hline $5 \mathrm{ng} / \mathrm{ml}$ & $50 \pm 17$ & & \\
\hline $50 \mathrm{ng} / \mathrm{ml}$ & $66 \pm 14^{\ddagger}$ & ND & ND \\
\hline $500 \mathrm{ng} / \mathrm{ml}$ & $44 \pm 15$ & & \\
\hline \multicolumn{4}{|l|}{ IL- $1 \beta$} \\
\hline $50 \mathrm{pg} / \mathrm{ml}$ & $89 \pm 1^{*}$ & & \\
\hline $500 \mathrm{pg} / \mathrm{ml}$ & $103 \pm 16^{*}$ & ND & ND \\
\hline $5,000 \mathrm{pg} / \mathrm{ml}$ & $95 \pm 13^{*}$ & & \\
\hline \multicolumn{4}{|l|}{ IL-6 } \\
\hline $10 \mathrm{pg} / \mathrm{ml}$ & $48 \pm 5$ & & \\
\hline $100 \mathrm{pg} / \mathrm{ml}$ & $104 \pm 8^{*}$ & ND & $293 \pm 11^{*}$ \\
\hline $1,000 \mathrm{pg} / \mathrm{ml}$ & $69 \pm 16^{*}$ & & \\
\hline \multicolumn{4}{|l|}{ M-CSF } \\
\hline $5 \mathrm{pg} / \mathrm{ml}$ & $49 \pm 5$ & $97 \pm 14^{*}$ & \\
\hline $50 \mathrm{pg} / \mathrm{ml}$ & $79 \pm 11^{*}$ & $96 \pm 8^{*}$ & ND \\
\hline $500 \mathrm{pg} / \mathrm{ml}$ & $83 \pm 6^{*}$ & $92 \pm 26^{\ddagger}$ & \\
\hline \multicolumn{4}{|l|}{ Calcitonin } \\
\hline $1 \mathrm{U} / \mathrm{ml}$ & ND & $33 \pm 5^{*}$ & ND \\
\hline
\end{tabular}

Bone marrow nonadherent mononuclear cells $\left(1 \times 10^{5} /\right.$ well $)$ were cultured in $\alpha$ MEM containing $20 \%$ horse serum with and without $1,25(\mathrm{OH})_{2} \mathrm{D}_{3}$, bovine 1-34 PTH, recombinant human IL- $1 \beta$, recombinant human IL-6, or recombinant human M-CSF for 3 wk. The cells were stained with $23 \mathrm{C} 6$, which preferentially binds to osteoclasts, followed by staining with avidin-biotin conjugated rabbit anti-mouse IgG coupled to alkaline phosphatase using the ABC-AP kit. In the case of the normal control, $\sim 10023$ C6-positive osteoclast-like cells/ well were usually formed (see Results). Note that the number of osteoclast-like cells formed from the patient's bone marrow was only $40 \%$ of the normal control. $1,25(\mathrm{OH})_{2} \mathrm{D}_{3}$, PTH, IL- $1 \beta$, IL-6, and $\mathrm{M}-\mathrm{CSF}$ each significantly increased the number of 23C6-positive osteoclast-like cells compared to the number without any treatment. ${ }^{*} P<0.01 ;{ }^{\ddagger} P<0.05$. ND, Not done.

dentin slices, numerous resorption lacunae were observed, as previously reported (18). In contrast, in the case of the patientderived osteoclast-like cells, no resorption lacunae were observed either in the absence or presence of the hormones or growth factors listed in the experiment (Fig. 2).

Vacuolar proton pump. As the normal control, the osteoclast-like cells obtained from normal bone marrow cells clearly contained the vacuolar proton pump, which is detected by the E11 antibody. In contrast, the osteoclast-like cells from the CMD patient did not show any proton pump (Fig. 3).

Western blot analysis. As the normal control, clear bands were observed at a molecular mass of $60 \mathrm{kD}$, indicating the expression of pp60 ${ }^{\text {c-src }}$ in the platelet-rich plasma of the normal control. There was comparable expression of pp60 $0^{\text {c-src }}$ in both the patient and the mother (Fig. 4). 

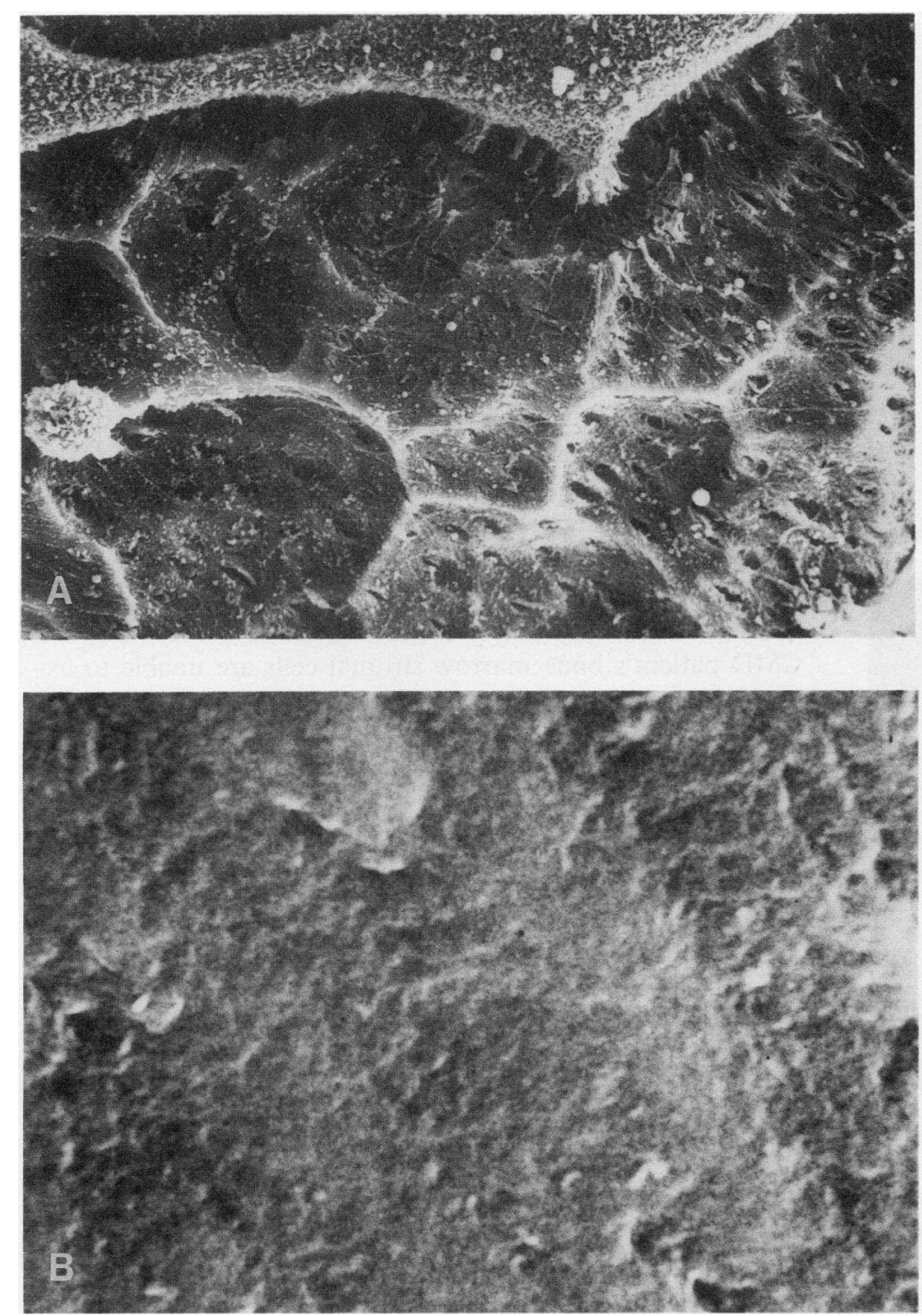

Figure 2. Resorption lacunae formed on dentin slices by osteoclast-like cells from patient bone marrow cells. Osteoclast-like cells were cultured for 1 wk on sperm whale dentin slices with $\alpha$ MEM-20\% horse serum containing recombinant human IL- $1 \beta(500 \mathrm{pg} / \mathrm{ml})$. Then, the dentin slices were examined by scanning electron microscopy. $(A)$ In the normal control, numerous resorption lacunae are observed. $(B)$ In the CMD patient, no resorption lacunae are observed.

\section{Discussion}

CMD is a rare hereditary sclerosing bone disease characterized by hyperostosis of the skull and abnormal metaphyseal bone modeling in the long bones (1-6). In this disease, the hyperostosis is usually localized in the skull but sometimes in the diaphyses of the long bones; this distinguishes it from osteopetrosis (7), another typical sclerosing bone disease. The clinical symptoms of CMD patients, such as hearing loss, visual disturbance and facial nerve palsy, are thought to be derived from compression of the cranial nerves due to the skull hyperostosis (5), while neither anemia nor hepatosplenomegaly have been reported in this disease (5). In our case, the roentogenograms, clinical symptoms and laboratory data all led to the diagnosis of CMD.

Although the pathogenesis of CMD remains obscure, two hypotheses have been postulated. First, bone resorption is reduced due to osteoclast dysfunction (5) and second, increased bone formation occurs secondarily due to increased bone remodeling (24). The former hypothesis is based on an autopsy report showing osteoclast deficiency in the cranial bone of a CMD patient (5). Recent successful treatment of a CMD pa- tient using a low calcium diet and pharmacological doses of $1,25(\mathrm{OH})_{2} \mathrm{D}_{3}(25)$ also suggests that reduced bone resorption by osteoclasts may be involved in the pathogenesis of CMD, because $1,25(\mathrm{OH})_{2} \mathrm{D}_{3}$ is known to stimulate bone resorption (26). In contrast, Fanconi et al. (24) reported the case of a CMD patient showing low serum calcium levels and secondary hyperparathyroidism. He treated the patient successfully with calcitonin to reduce bone formation secondary to high bone turnover. In our case, the serum calcium and PTH levels were all normal, while the serum osteocalcin level, a marker of bone formation (27), was low compared to age-matched normal controls, and suggests that increased bone formation was not associated with the pathogenesis of our CMD patient.

Recently, Kurihara et al. (18) established a culture method for isolating osteoclast-like cells from human bone marrow cells. Osteoclasts originate from the bone marrow (28), and their function is to resorb bone. Osteoclasts satisfy the following criteria: possession of calcitonin receptors (29), high tartrate-resistant acid phosphatase activity (30), and reaction with 23C6 (CD51) antibody, which recognizes vitronectin- $\beta$ receptors (31). This antibody has been proven to react with osteoclasts in human bone biopsy samples (32). Osteoclasts 

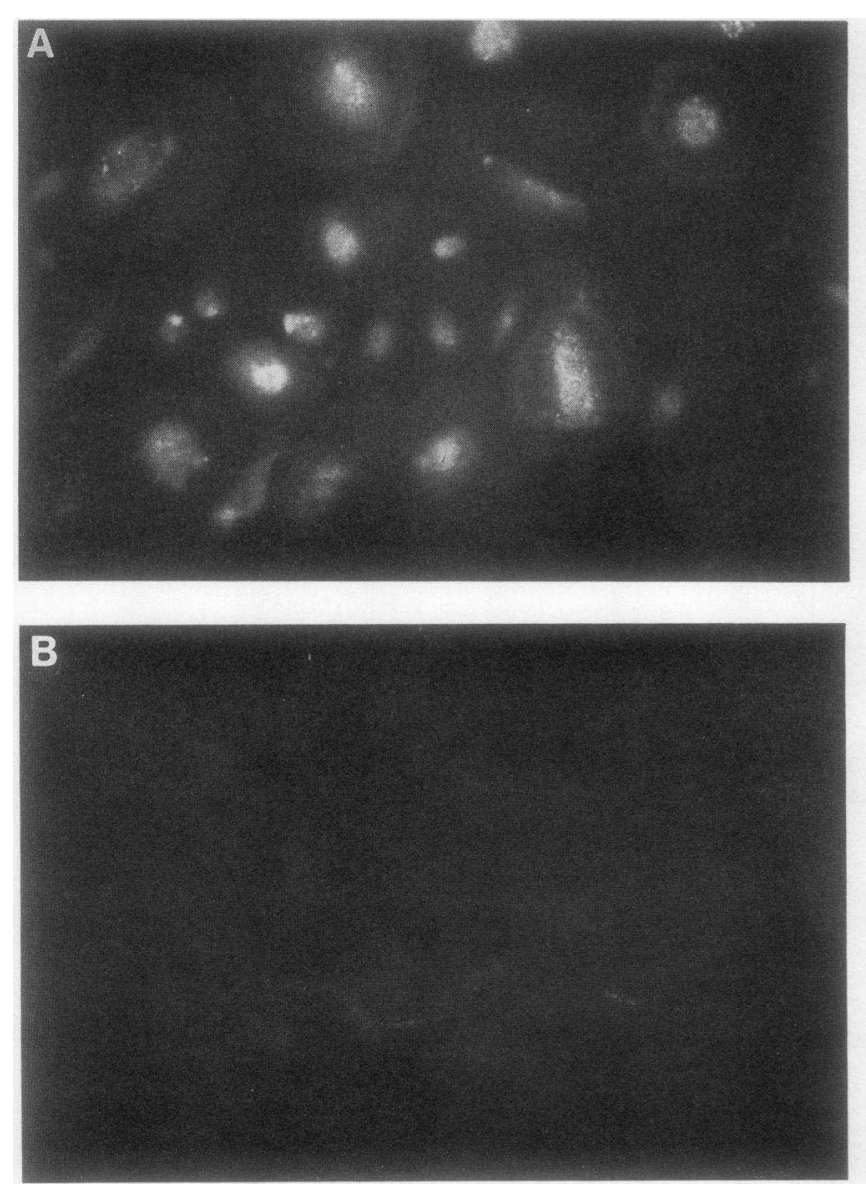

Figure 3. Vacuolar proton pump in osteoclast-like cells of a CMD patient. Bone marrow cells were treated with $10^{-8} \mathrm{M} 1,25(\mathrm{OH})_{2} \mathrm{D}_{3}$ for $3 \mathrm{wk}$ to obtain osteoclast-like cells. Then, the cells were stained with an antibody (E11) reacted with the osteoclast vacuolar proton pump. $(A)$ In the normal control, the proton pump has been detected in the cytoplasmic vesicles. $(B)$ In the CMD patient, no proton pump has been detected.

have also been reported to react with E11 antibody (15), which recognizes the vacuolar proton pump-whose function is to secrete hydrogen ions in bone resorption (15). Osteoclast-like cells formed from bone marrow cells by the method of Kurihara (18) met all these criteria for osteoclasts, although only $\sim 50 \%$ of the 23C6-positive cells reacted with E11 antibody, and only those cells were capable of resorbing bone $(19,23)$.

The hypothesis that osteoclast dysfunction causes reduced bone resorption was evaluated by using the osteoclast-like cells formed from the bone marrow cells. The formation of 23C6-positive cells was partially impaired in our CMD patient, corresponding to only $\sim 40 \%$ of the normal control formation of osteoclast-like cells in the presence or absence of various hormones and growth factors. Moreover, the osteoclast-like cells from this patient were unable to resorb dentin slices using our in vitro bone resorbing assay. Further investigation revealed that osteoclast-reactive vacuolar proton pump expression was completely lacking in the osteoclast-like cells from this CMD patient, even after stimulation with various hormones and growth factors. Since this osteoclast-reactive vacuolar proton pump was reported to be expressed in osteoclasts during differentiation (19), it is speculated that the lack of expression of osteoclast-reactive vacuolar proton pump in a CMD patient might be due to defective osteoclast maturation, and that this defect might be linked to the hyperostosis in our present CMD patient.

A question might arise concerning the absence of systemic bone sclerosis in our patient, which contradicts the finding of osteoclast dysfunction even in the osteoclast-like cells obtained from the bone marrow cells of unaffected bones from the patient. This discrepancy might be explained by the fact that some stromal cells (33) or osteoblastic cells (34), or direct contact of stromal cells with osteoclast precursor cells (35), is important for osteoclast differentiation. In our study, we used a mononuclear cell fraction of the bone marrow cells as the materials for obtaining osteoclast-like cells. Thus, some residual bone marrow stromal cells were speculated to cooperate with exogenous growth factors or hormones in vitro, resulting in the formation of mature osteoclasts in the normal control. Consequently, it is possible that local growth factors derived from this CMD patient's bone marrow stromal cells are unable to express the vacuolar proton pump in vitro. This hypothesis could be proven if co-culture of the patient's bone marrow and normal bone marrow stromal cells were able to correct the defective bone resorbing activity of the patient's osteoclast-like cells. However, this experiment was unable to be performed because no normal bone marrow stromal cells were available at the same time. Thus, it is speculated that the localized cranial hyperostosis and the metaphyseal long bone dysplasia in our CMD patient might be caused by abnormal function of local stromal cells, which are unable to differentiate localized osteoclast precursors into mature osteoclasts, resulting in the impaired expression of the vacuolar proton pump in the osteoclasts. The importance of local factors in our patient is also suggested by the state of high bone turnover, as evidenced by the elevated serum alkaline phosphatase activity and urinary hydroxyproline excretion, in spite of normal levels of such serum systemic calcitropic hormones as $1,25(\mathrm{OH})_{2} \mathrm{D}_{3}, \mathrm{PTH}$, and calcitonin.

Recently, Soriano et al. (13) obtained evidence suggesting that protooncogene c-src was associated with osteoclastic bone resorption in an osteopetrotic transgenic mouse model. This finding suggested the possibility that defective protooncogene c-src expression might be linked to the impaired osteoclastreactive vacuolar proton pump in our CMD patient. However, that is not plausible, because we found the levels of pp60 $0^{\mathrm{c}-\mathrm{src}}$ in platelets of our CMD patient to be comparable to the normal control. Thus, the pathophysiology of our CMD patient cannot be explained by abnormal function of the protooncogene c-src. Further study is thus necessary to elucidate the etiology of abnormal bone metabolism in CMD patients.

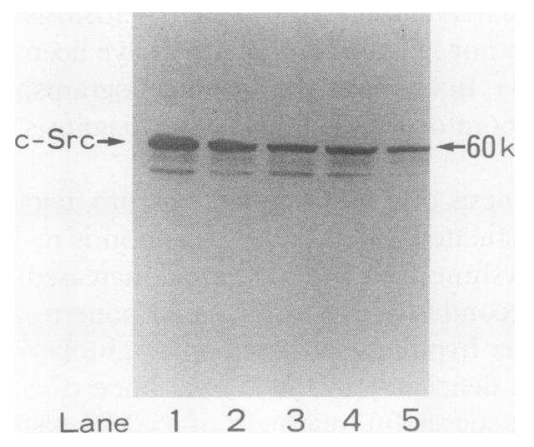

Figure 4. Western blot analysis of pp $60^{\mathrm{c}-\mathrm{src}}$ in platelet-rich plasma fraction. Anti-c-src monoclonal antibody (327) was used for immunostaining of the protein bands (see Methods). (Lane 1) Patient; (lane 2) mother; (lanes 3-5) normal controls. 
In conclusion, a defect in osteoclast-reactive vacuolar proton pump expression was proven in our CMD patient. Our data support the hypothesis that osteoclast dysfunction explains the hyperostosis and the metaphyseal bone dysplasia in CMD patients.

\section{Acknowledgments}

We thank Dr. Francis H. Glorieux (Genetics Unit, Shriners Hospital, Montreal, Canada), Dr. Steven L. Teitelbaum (Department of Pathology, Jewish Hospital of St. Louis at Washington University Medical Center), and Dr. Toshiyuki Yoneda (Endocrinology \& Metabolism, Department of Medicine, University of Texas Health Science Center, San Antonio, Texas) for their helpful suggestions for this study.

\section{References}

1. Spranger, J., K. Paulsen, and W. Lehmann. 1965. Die kraniometaphysäre dysplasie (Pyle). Z. Kinderheilkd. 93:64-79.

2. Rimoin, D. L., S. L. Woodruff, and B. L. Holman. 1969. Craniometaphyseal dysplasia (Pyle's disease): autosomal dominant inheritance in a large kindred. Birth Defects Orig. Artic. Ser. 5:96-104.

3. Spiro, P. C., H. Hamerama, and P. Beighton. 1975. Radiology of the autosomal dominant form of craniometaphyseal dysplasia. S. Afr. Med. J. 49:839842.

4. Ross, M. W., and D. H. Altman. 1967. Familial metaphyseal dysplasia: review of the clinical and radiological features of Pyle's disease. Clin. Pediatr. 6:143-149.

5. Millard, D. R., D. O. Maisels, J. H. F. Batstone, and B. W. Yates. 1967. Craniofacial surgery in craniometaphyseal dysplasia. Am. J. Surg. 113:615-621.

6. Penchaszadeh, V. B., E. R. Gutierrez, and F. P. Ernesto. 1980. Autosomal recessive craniometaphyseal dysplasia. Am. J. Med. Genet. 5:43-55.

7. Johnston, C. C., N. Lary, T. Lord, F. Vellois, A. D. Merritt, and W. P. Deiss. 1968. Osteopetrosis: a clinical, genetic metabolic and morphologic study of dominantly inherited, benign form. Medicine (Baltimore) 47:149-167.

8. Marks, S. C., Jr., and D. G. Walker. 1982. Transformations of osteoclast phenotype in ia rats cured of congenital osteopetrosis. J. Morphol. 174:141-147.

9. Marks, S. C., Jr., and D. G. Walker. 1981. The hematogenous origin of osteoclasts: experimental evidence from osteopetrotic (microphthalmic) mice treated with spleen cells from beige mouse donors. Am. J. Anat. 161:1-10.

10. Wiktor-Jedrzjczak, W., A. Ahmed, C. Szczylik, and R. R. Skelly. 1982. Hematological characterization of congenital osteopetrosis in op/op mouse: possible mechanism for abnormal macrophage differentiation. J. Exp. Med. 156:1516-1527.

11. Felix, R., M. G. Cecchini, W. Hofstetter, P. R. Elford, A. Stutzer, and H. Fleisch. 1990. Impairment of macrophage colony-stimulating factor production and lack of resident bone marrow macrophages in the osteopetrotic op/op mouse. J. Bone Miner. Res. 5:781-789.

12. Yoshida, H., S. Hayashi, T. Kunisada, M. Ogawa, S. Nishikawa, H. Okamura, T. Sudo, L. D. Shutz, and S. Nishikawa. 1990. The murine mutation osteopetrosis is in the coding region of the macrophage colony stimulating factor gene. Nature (Lond.). 345:442-444.

13. Soriano, P., C. Montgomery, R. Geske, and A. Bradley. 1991. Targeted disruption of the c-src proto-oncogene leads to osteopetrosis in mice. Cell. 64:693-702.

14. Horton, M. A., D. Lewis, K. Munulty, J. A. S. Pringle, and T. J. Chambers. 1985. Monoclonal antibodies to osteoclastomas (giant cell bone tumors): definition of osteoclast specific cellular antigens. Cancer Res. 45:56635669 .

15. Blair, H. C., S. L. Teitelbaum, R. Chiselli, and S. Gluck. 1989. Osteoclastic bone resorption by a polarized vacuolar proton pump. Science (Wash. DC). 245:855-857.

16. Nakatsuka, K., T. Miki, Y. Nishizawa, T. Tabata, T. Inoue, H. Morii, and
E. Ogata. 1991. Circulating bone gla protein in end stage renal disease determined by newly developed two-site immunoradiometric assay. In: Contributions to $\mathrm{Ne}$ phrology. G. M. Berlyne and S. Giovannetti, editors. S. Karger AG, Basel. 147154.

17. Yamaoka, K., H. Tanaka, H. Kurose, M. Shima, K. Ozono, S. Nakajima, and Y. Seino. 1989. Effect of single oral phosphate loading on vitamin D metabolites in normal subjects and in X-linked hypophosphatemic rickets. Bone Miner. 7:159-169.

18. MacDonald, B. R., N. Takahashi, L. M. Mcmanus, J. Holahan, G. R. Mundy, and G. D. Roodman. 1987. Formation of multinucleated cells that respond to osteotropic hormones in long term human bone marrow cultures. Endocrinology. 20:2326-2333.

19. Kurihara, N., S. Gluck, and G. D. Roodman. 1990. Sequential expression of phenotype markers for osteoclasts during differentiation of precursors for multinucleated cells formed in long-term human marrow cultures. Endocrinology. 127:3215-3221.

20. Lipsich, L. A., A. J. Lewis, and J. S. Brugge. 1983. Isolation of monoclonal antibodies that recognize the transforming proteins of avian sarcoma viruses. $J$. Virol. 48:352-360.

21. Cooper, J. A., and K. Runge. 1987. Avian pp60 6 c-src is more active when expressed in yeast than in vertebrate fibroblasts. Oncogene Res. 1:297-310.

22. Nada, S., M. Okada, A. MacAuley, J. A. Cooper, and H. Nakagawa. 1991. Cloning of a complementary DNA for a protein-tyrosine kinase that specifically phosphorylates a negative regulatory site of p60 c-src . Nature (Lond.). 351:69-72.

23. Kurihara, N., C. Civin, and G. D. Roodman. 1991. Osteotropic factor responsiveness of highly purified populations of early and late precursors for human multinucleated cells expressing the osteoclast phenotype. J. Bone Miner. Res. 6:257-261.

24. Fanconi, S., J. A. Fisher, P. Wieland, A. Giedion, E. Boltshauser, A. J. Olah, A. M. Landolt, and A. Prader. 1988. Craniometaphyseal dysplasia with increased bone turnover and secondary hyperparathyroidism: therapeutic effect of calcitonin. J. Pediatr. 112:587-591.

25. Key, L. L., F. Volberg, R. Baron, and C. S. Anast. 1988. Treatment of craniometaphyseal dysplasia with calcitriol. J. Pediatr. 112:583-587.

26. Stewart, P. J., and P. H. Stern. 1987. Vertebral bone resorption in vitro: effect of parathyroid hormone, calcitonin, 1,25-dihydroxyvitamin $D_{3}$ epidermal growth factor, prostaglandin $\mathrm{E}_{2}$ and estrogen. Calcif. Tissue Int. 40:21-26.

27. Brown, J. P., L. Malaval, M. C. Chapuy, P. D. Delmas, C. Edouard, and P. J. Meunier. 1984. Serum bone gla-protein: a specific marker of bone formation in postmenopausal osteoporosis. Lancet. i:1091-1093.

28. Scheven, B. A. A., J. W. M. Visser, and P. J. Nijweide. 1986. In vitro osteoclast generation from different bone marrow fractions, including a highly enriched hematopoietic stem cell population. Nature (Lond.). 321:79-81.

29. Hattersley, G., and T. J. Chambers. 1989. Calcitonin receptors as markers for osteoclastic differentiation: correlation between generation of bone-resorptive cells and cells that express calcitonin receptors in mouse bone marrow cultures. Endocrinology. 125:1606-1612.

30. Takahashi, N., H. Yamana, S. Yoshiki, G. D. Roodman, G. R. Mundy, S. J. Jones, A. Boyde, and T. Suda. 1988. Osteoclast-like cell formation and its regulation by osteotropic hormones in mouse bone marrow cultures. Endocrinology. 122:1373-1382.

31. Davis, J., J. Warwick, N. Totty, P. Philip, M. Helfrich, and M. Horton. 1989. The osteoclast functional antigen, implicated in the regulation of bone regulation, is biochemically related to the vitronectin receptor. J. Cell Biol. 109:1817-1826.

32. Horton, M. A. 1988. Osteoclast-specific antigens. ISI Atlas Sci. Immunol. $35-43$.

33. Udagawa, N., N. Takahashi, T. Akatsu, T. Sasaki, A. Yamaguchi, H. Kodama, T. J. Martin, and T. Suda. 1989. The bone marrow-derived stromal cell lines MC3T3-G2/PA6 and ST2 support osteoclast-like cell differentiation in cocultures with mouse spleen cells. Endocrinology. 125:1805-1813.

34. Takahashi, N., T. Akatsu, N. Udagawa, T. Sasaki, A. Yamaguchi, J. M. Moseley, T. J. Martin, and T. Suda. 1988. Osteoblastic cells are involved in osteoclast formation. Endocrinology. 123:2600-2602.

35. Udagawa, N., N. Takahashi, T. Akatsu, H. Tanaka, T. Sakai, T. Nishihara, T. Koga, T. J. Martin, and T. Suda. 1990. Origin of osteoclasts: mature monocytes and macrophages are capable of differentiating into osteoclasts under a suitable microenvironment prepared by bone marrow-derived stromal cells. Proc. Natl. Acad. Sci. USA. 87:7260-7264. 